\title{
PENGARUH MODEL PEMBELAJARAN INKUIRI TERHADAP HASIL BELAJAR SISWA PADA MATERI POKOK LISTRIK DINAMIS DI KELAS X SEMESTER II SMA NEGERI 8 MEDAN T.P. 2013/2014
}

\author{
Sehat Simatupang dan Tiarmaida \\ Prodi PendidikanFisika FMIPA Unimed
}

\begin{abstract}
ABSTRAK
Penelitian ini bertujuan untuk mengetahui peningkatanaktivitas dan pengaruh penerapan model pembelajaran inkuiri terhadap hasil belajar siswa. Jenis penelitian ini adalah kuasi eksperimendengan populasi dalam penelitian adalah seluruh siswa kelas X SMA Negeri 8 Medan yang terdiri dari 12 kelas. Pengambilan sampel dilakukan dengan cara cluster random sampling dengan mengambil 2 kelas dari 12 kelas secara acak yaitu kelas X4 sebagai kelas eksperimen dan kelas X-6 sebagai kelas kontrol. Instrumen yang digunakan dalam penelitian ini adalah tes hasil belajar dalam bentuk pilihan berganda dengan jumlah 20 soalyang telah divalidkan danlembar observasi aktivitas belajar siswa. Nilai rata-rata hasil belajar siswa yang diberi perlakuan dengan model pembelajaran inkuiri adalah 71,67 dan dengan pembelajaran konvensional adalah 64,5. Peningkatan aktivitas belajar siswa selama mengikuti pembelajaran dengan menggunakan model pembelajaran inkuiri adalah 63,36 dan dengan menggunakan pembelajaran konvensional adalah 56,47 yang termasuk pada kriteria nilai rendah. Berdasarkan hasil analisis perhitungan uji t, terdapat pengaruh yang signifikan penerapan model pembelajaran inkuiri terhadap hasil belajar siswa.
\end{abstract}

Kata kunci : Model pembelajaran inkuiri, hasil belajar, peningkatan aktivitas.

\section{PENDAHULUAN}

Pendidikan pada hakikatnya bertujuan untuk mengembangkan potensi peserta didik agar menjadi manusia yang kreatif dan mandiri (Trianto, 2009: 1). Berbagai upaya telah dilakukan untuk mencapai tujuan pendidikan tersebut, salah satunya dengan penerapan teknologi pendidikan yang sesuai, sehingga dapat mendukung pembangunan di masa mendatang.

Di Indonesia, teknologi pendidikan yang berkembang adalah teknologi yang berorientasi pada kemampuan. Hal ini dikemukakan dalam Undang-Undang Nomor 20 Tahun 2003 tentang Sistem Pendidikan Nasional yang menyebutkan "bahwa pendidikan nasional berfungsi mengembangkan kemampuan dan membentuk watak serta peradaban bangsa yang bermartabat dalam rangka mencerdaskan kehidupan bangsa".

Pendidikan yang berorientasi pada kemampuan ini menghadapi berbagai tantangan yang tidak bisa ditanggulangi dengan cara lama, sehingga ilmu pengetahuan dan teknologi yang berkembang cepat, tidak dapat diikuti oleh guru maupun siswa. Guru yang hanya menyampaikan materi pokok pengetahuan kepada siswa di kelas akan menimbulkan permasalahan dalam pembelajaran, karena materi pokok pengetahuan yang diberikan tidak sesuai dengan perkembangan yang ada di masyarakat. 
Adapun permasalahan yang timbul dalam pembelajaran pada umumnya adalah rendahnya daya serap siswa, khususnya dalam pelajaran fisika. Fisika dianggap sebagai pelajaran yang sulit dan membosankan sehingga siswa tidak termotivasi dalam mempelajari fisika. Hal ini sejalan dengan hasil angket di SMA Negeri 8 Medan, sebanyak 53\% siswa beranggapan fisika merupakan pelajaran yang sulit dan membosankan, padahal kenyataannya fisika bukanlah pelajaran yang sulit dan membosankan melainkan pelajaran yang menarik, karena fisika bukan hanya berupa soal atau perhitungan matematis saja melainkan berupa konsep dan gejala alam yang dialami dalam kehidupan sehari-hari.

Rendahnya daya serap siswa dalam pelajaran fisika juga berdampak pada hasil belajar siswa. Berdasarkan hasil wawancara dengan salah seorang guru fisika di SMA Negeri 8 Medan mengatakan bahwa hasil belajar siswa tergolong rendah, hanya $40 \%$ siswa lulus KKM (Kriteria Ketuntasan Minimal) yang mana KKM fisika adalah 70. Hasil belajar yang rendah merupakan hasil pembelajaran yang masih bersifat konvensional dan tidak menyentuh seluruh ranah dimensi siswa yakni ranah kognitif, keterampilan dan sikap. Pembelajaran yang dilakukan masih terbatas pada ranah kognitif saja dan masih didominasi oleh guru (teacher centered) yang tidak memberikan akses bagi siswa untuk berkembang secara kreatif dan mandiri melalui peningkatan aktivitas siswa.

Berdasarkan pemaparan masalah di atas, salah satu cara yang dilakukan untuk memperbaiki proses pembelajaran adalah dengan menerapkan model pembelajaran inkuiri. Dengan menggunakan model pembelajaran inkuiri diharapkan dapat meningkatkan aktivitas siswa melalui proses berpikir sendiri, berdiskusi dan menganalisis dalam tahap-tahap penyajian masalah, pengumpulan data, pelaksanaan eksperimen, pengorganisasian data dan perumusan masalah sehingga siswa dapat menemukan konsep berdasarkan bahan yang telah disediakan guru. Selain peningkatan aktivitas siswa, inkuiri juga dapat meningkatkan hasil belajar siswa, karena penerapan model pembelajaran inkuiri dapat melatih siswa untuk berpikir secara logis dan sistematis serta lebih percaya diri mengemukakan apa yang ditemukan melalui proses inkuiri. Dalam model pembelajaran inkuiri, guru berperan sebagai : (1) motivator, artinya guru mendorong siswa agar dapat berpikir kritis melalui penyajian masalah, (2) fasilisator, artinya guru membantu siswa ketika mengalami kesulitan, dan (3) pengarah, artinya guru memimpin siswa agar mencapai tujuan pembelajaran yang diharapkan.

Penelitian tentang penggunaan model pembelajaran inkuiri telah dilakukan oleh Lubis (2011) dengan judul penelitian "Pengaruh Model Pembelajaran Inquiry Terhadap Hasil Belajar Siswa Kelas VII Semester II Di SMP Negeri 2 Medan pada Materi Pokok Suhu dan Pengukuran Tahun Pelajaran 2010/2011", diperoleh nilai rata-rata pretes 35,38 dan setelah diberi perlakuan model pembelajaran inkuiri memperoleh rata-rata 70,25. Selain ada peningkatan, ada kelemahan dalam penelitian ini. Adapun kelemahan dalam penelitian ini adalah waktu yang digunakan dalam pembelajaran kurang efisien, sehingga proses pembelajaran tidak berlangsung secara maksimal. Peneliti juga mengalami kesulitan dalam pengelolaan kelas sehingga kondisi kelas tidak kondusif selama pembelajaran berlangsung.

Demikian juga hasil penelitian Azmi (2010) yang berjudul "Perbedaan Model Pembelajaran Inkuiri dengan Model Pembelajaran Konvensional Terhadap Hasil Belajar Siswa pada Materi Pokok Listrik Dinamis Semester 2 SMA Negeri 1 Pangkalan Susu T.P 2009/2010”, diperoleh bahwa hasil belajar fisika yang 
menerapkan model pembelajaran inkuiri memiliki rata-rata sebesar 56 sedangkan hasil belajar siswa dengan model pembelajaran konvensional memiliki ratarata sebesar 51. Ini berarti hasil yang dicapainya cukup baik karena terdapat perbedaan yang signifikan. Adapun kelemahan dari penelitian ini adalah penyajian masalah yang kurang menarik dan kurang menggugah rasa ingin tahu siswa sehingga siswa kurang termotivasi dalam menemukan jawaban dari permasalahan yang disajikan.

Untuk mengatasi hal-hal tersebut, peneliti akan mempersiapkan model pembelajaran inkuiri dengan memperhatikan alokasi waktu yang digunakan agar berjalan sesuai rencana dan peneliti juga akan semaksimal mungkin mengawasi proses pembelajaran agar kondisi kelas tetap kondusif. Selain itu, peneliti menggunakan peta konsep agar menarik minat siswa dalam belajar dan mengingat pokok-pokok penting materi pembelajaran.

Berdasarkan uraian latar belakang masalah di atas, penulis tertarik melakukan penelitian dengan judul: "“ Pengaruh Model Pembelajaran Inkuiri terhadap Hasil Belajar Siswa pada Materi Pokok Listrik Dinamis di Kelas X Semester II SMA Negeri 8 Medan T.P. 2013/2014".

\section{METODE PENELITIAN}

Penelitian ini dilaksanakan di SMA Negeri 8 Medan dengan populasi seluruh siswa kelas X SMA Negeri 8 Medan yang terdiri dari 12 kelas. Teknik pengambilan sampel dilakukan dengan cara teknik sampel kelas acak (cluster random sampling). Sampel kelas diambil dari populasi sebanyak dua kelas yaitu kelas X-4 dengan menggunakan model pembelajaraninkuiri dan kelas $\mathrm{X}$ 6dengan menggunakan pembelajaran konvensional. Jenis penelitianiniadalahkuasieksperimen ini dengan desain two group pretest-postest designseperti yangditunjukkanpadaTabel 1.

Tabel 1. Desain Penelitian tipe Two GroupPretest-Postest

\begin{tabular}{|c|c|c|c|}
\hline Kelas & Pretes & Perlakuan & Postes \\
\hline Eksperimen & $\mathrm{Y}_{1}$ & $\mathrm{X}_{1}$ & $\mathrm{Y}_{2}$ \\
\hline Kontrol & $Y_{1}$ & $\mathrm{X}_{2}$ & $\mathrm{Y}_{2}$ \\
\hline
\end{tabular}

Keterangan:

$\mathrm{X}_{1}=$ Pembelajaran dengan menggunakan model pembelajaran inkuiri

$\mathrm{X}_{2}=$ Pembelajaran denganmenggunakan pembelajaran konvensional

$\mathrm{Y}_{1}=$ Pretes diberikan pada kelas eksperimen dan kelas kontrol sebelum perlakuan.

$\mathrm{Y}_{2}=$ Postes diberikan setelah perlakuan pada kelas eksperimen dan kelas kontrol.

Alat pengumpul data dalam penelitian ini adalah tes berbentuk pilihan berganda untuk mengetahui hasil belajar siswa pada ranah kognitif dan lembar observasi untuk mengetahui peningkatan aktivitassiswa.

Uji hipotesis yang
digunakandenganmenggunakanuji $\mathrm{t}$ dengan membandingkan rata-rata skor hasil belajar yang dicapai baik kelas eksperimen maupun kelas kontrol. Data yang diperoleh ditabulasikan kemudian dicari rata-ratanya. Sebelum dilakukan penganalisisan data, terlebih dahulu ditentukan skor masing-masing kelompok sampel lalu dilakukan pengolahan data dengan langkahlangkah sebagai berikut:
a) Menghitung nilai rata-rata dan simpangan baku
b) Uji normalitas
c) Uji homogenitas
d) Ujikesamaan rata-rata pretes

Uji t digunakan untuk mengetahui kesamaan kemampuan awal siswa pada kedua kelompok sampel. Hipotesis yang diuji berbentuk : 
$\mathrm{H}_{\mathrm{o}}$ : kelas eksperimen dan kelas kontrol mempunyai kemampuan awal yang sama.

$\mathrm{H}_{\mathrm{a}}$ : kelas eksperimen dan kelas kontrol mempunyai kemampuan awal yang berbeda.

e) Pengujian hipotesis

Uji $t$ jugadigunakan untuk mengetahui perbedaan dari suatu perlakuan yaitu model pembelajaraninkuiriterhadap hasil belajar siswa. Hipotesis yang diuji berbentuk:

$\mathrm{H}_{\mathrm{o}}$ : Tidak ada perbedaan hasil belajar siswa akibat pengaruh model pembelajaran inkuiri dengan pembelajaran konvensional.

$\mathrm{H}_{\mathrm{a}}$ : Ada perbedaan hasil belajar siswa akibat pengaruh model pembelajaran model pembelajaran inkuiri dengan pembelajaran konvensional.

\section{HASIL PENELITIAN PEMBAHASAN}

\section{HasilPenelitian}

Sebelum dilakukan perlakuan pada penelitian terlebih dahulu diberikan tes pendahuluan untuk mengetahui kemampuan awal siswa pada kedua kelompok sampel, diperoleh nilai ratarata kelas eksperimen sebesar 39,83 dengan standar deviasi 12,28 sedangkan nilai rata-rata pada kelas kontrol sebesar 38,67 dengan standar deviasi 12,9. Setelah memperoleh data hasil tes pendahuluan siswa dari kelas eksperimen dan kelas kontrol, maka dilakukan terlebih dahulu pengujian analisa data berupa uji normalitas dan uji homogenitas data pretes untuk mengetahui kelayakannya sebelum diberikan perlakuan. Hasilujinormalitas, homogenitasdankesamaan rata-rata pretesditunjukkan pada Tabel2.

\begin{tabular}{llllll}
\hline Kelas & $\begin{array}{c}\text { Rata- } \\
\text { rata }\end{array}$ & $\begin{array}{l}\mathbf{F}_{\text {hitun }} \\
\mathbf{g}\end{array}$ & $\begin{array}{l}\mathbf{F}_{\text {tab }} \\
\text { el }\end{array}$ & $\mathbf{t}_{\text {hit }}$ & $\mathbf{t}_{\text {tab }}$ \\
\hline $\begin{array}{l}\text { Eksp } \\
\text { erim } \\
\text { en }\end{array}$ & 39,83 & & & & \\
Kont & 38,67 & 1,11 & 1,8 & 0,3 & 2,0 \\
rol & & 9 & 6 & 1 \\
\hline Kesimpulan & Homogen & & $\begin{array}{l}\text { Kemampua } \\
\text { nawalsiswa } \\
\text { sama }\end{array}$ \\
\hline
\end{tabular}

BerdasarkanTabel 2 data pretes kedua kelas normal, homogen dan tidak ada perbedaan secara signifikan, maka pada kedua kelas sampel diberikan perlakuan yang berbeda, pada kelas eksperimen diberikan perlakuan dengan menerapkan model pembelajaran inkuiri sedangkan pada kelas kontrol diberikan perlakuan dengan menerapkan pembelajaran konvensional.Setelah diberikan perlakuan yang berbeda, kedua kelas diberikan postes untuk melihat adanya perbedaan akibat penerapan model pembelajaran yang berbeda. Hasil rata-rata postes kelas eksperimen memperoleh nilai rata- rata 71,67 , sedangkan nilai rata-rata postes kelas kontrol adalah 64,5. Hasilujinormalitas, homogenitas dan hipotesissiswaditunjukkan pada Tabel 3.

Tabel 3. HasilUjiNormalitas, Homogenitas dan HipotesisSiswa 


\begin{tabular}{|c|c|c|c|c|c|}
\hline Kelas & $\begin{array}{l}\text { Rat } \\
\text { a- } \\
\text { rata }\end{array}$ & $\mathbf{F}_{\text {hit }}$ & $\mathbf{F}_{\mathrm{tab}}$ & $\mathbf{t}_{\text {hit }}$ & $t_{\text {tab }}$ \\
\hline Ekspe & 71,6 & & & & \\
\hline rimen & 7 & 151 & 1,8 & 2,47 & 1.67 \\
\hline $\begin{array}{l}\text { Kontr } \\
\text { ol }\end{array}$ & 64,5 & & & & \\
\hline \multicolumn{2}{|c|}{ Kesimpulan } & \multicolumn{2}{|c|}{ Homogen } & \multicolumn{2}{|c|}{$\begin{array}{l}\text { Ada } \\
\text { perbedaa } \\
\text { n yang } \\
\text { signifika } \\
n\end{array}$} \\
\hline
\end{tabular}

BerdasarkanTabel 3 diperoleh bahwa data postes kedua kelas normal, homogen dan nilai $t_{\text {hitung }}>t_{\text {tabel }}$ yaitu $2,47>1,67$, sehingga dapat disimpulkan bahwa ada perbedaaan yang signifikan akibat pengaruh penerapan model pembelajaran inkuiri terhadap hasil belajar siswa.

\section{Peningkatan}

aktivitas siswa persentase skor rata- rata peningkatan aktivitas antara kelas eksperimen dan kelas kontrol sangat berbeda.Pada kelas eksperimen yang menggunakan model pembelajaran inkuiri termasukdalamkriteriasedang dan pada kelas kontrol dengan menerapkan pembelajaran konvensional termasukdalamkriteria rendah.Peningkatan aktivitas pada kelas eksperimen dan kelas kontroldapat dilihat pada Gambar 1 dan Gambar 2.
Gambar 1.Peningkatan Aktivitas pada Kelas Eksperimen
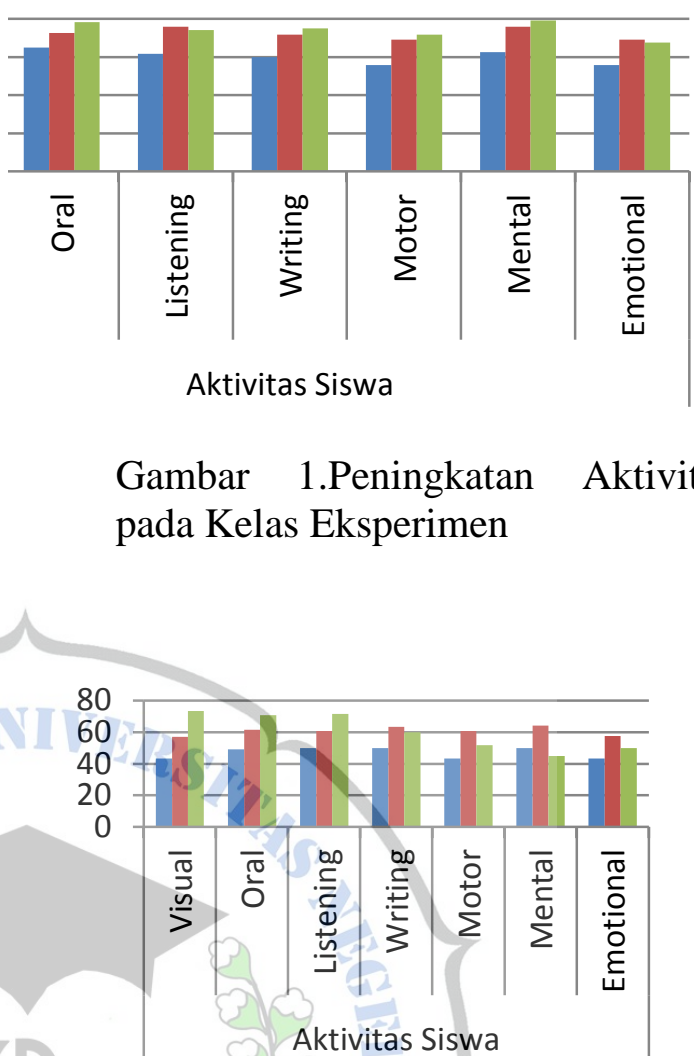

Gambar 2. Peningkatan aktivitas pada kelas kontrol

Berdasarkan Gambar 1 dan Gambar 2 dapat dilihat bahwa terjadipeningkatanaktivitaspadasetiapper temuan di kelaseksperimendankelaskontroldenganr ata-rata peningkatan aktivitas belajar siswa di kelas eksperimen lebih tinggi daripada kelas kontrol.

\section{Pembahasan}

Hasil penelitian menunjukkan bahwa hasil belajar fisika dengan menggunakan model pembelajaran inkuiri lebih baik daripada pembelajaran konvensional. Hal ini dibuktikan dengan perolehannilai rata-rata postes siswa kelas eksperimen sebesar 71,67, sedangkan rata-rata postes siswa kelas kontrol sebesar 64,5.

Hasil belajar fisika dengan menggunakan model pembelajaran 
inkuiri lebih baik daripada pembelajaran konvensional didasarkan pada banyak hal yaitu model pembelajaran inkuiri yang dapat membantu siswa untuk mengkonstruksi langsung pengetahuan melalui setiap kegiatan yang telah dirancang pada fase inkuiri. Adapun fase tersebut adalah 1) Penyajian masalah; Guru menyajikan masalah dan menyampaikan informasi dengan bantuan peta konsep tentang materi listrik dinamis agar siswa dapat mengingat pokok-pokok materi listrik dinamis yang diajarkan, 2) Membuat hipotesis; setiap siswa diberikan kesempatan untuk mengajukan pendapat dalam membentuk hipotesis, sehingga siswa belajar menyelesaikan masalah, berpikir logis dan kritis yakni dengan mengemukakan hipotesis, bertanya kepada guru, serta mengemukakan pendapat mengenai permasalahan yang disajikan, 3) Melakukan percobaan untuk memperoleh informasi; siswa melakukan percobaan untuk memperoleh jawaban dari hipotesis yang diajukan. Dalam hal ini, siswa didorong untuk belajar sendiri dan belajar aktif melalui proses penemuan konsep dalam percobaan; 4) Membuat kesimpulan; siswa dibimbing untuk membuat kesimpulan dari percobaan yang dilakukan.

Berdasarkan perolehan data peningkatan aktivitas siswa persentase skor rata-rata peningkatan aktivitas antara kelas eksperimen dan kelas kontrol sangat berbeda. Hal ini dikarenakan siswa saling berinteraksi dan bekerjasama dalam memperoleh informasi, yakni dengan pembentukan kelompok yang dipilih secara heterogen. Setiap anggota kelompok diwajibkan untuk mengerjakan percobaan sehingga siswa yang belum mengetahui cara menggunakan alat ukur listrik dapat bertanya pada anggota kelompok yang mengetahui penggunaan alat ukur tersebut sehingga terjadi interaksi maupun komunikasi yang baik antar anggota dalam kelompok.

Pada kelas kontrol, aktivitas belajar siswa kurang aktif, hal ini dikarenakan siswa kurang termotivasi dalam belajar, karena pembelajaran yang dilakukan tidak bervariasi. Selain itu, siswa juga jarang mengajukan pertanyaan meskipun mereka belum mengerti tentang materi yang disajikan.

Keadaan di atas sejalan dengan beberapa hasil penelitian yang menggunakan model pembelajaran kooperatiif tipe NHT, diantaranyaLubis (2011) di SMP Negeri 2 Medan pada materi pokok Suhu dan Pengukuran diperoleh nilai rata-rata pretes kelas eksperimen sebesar 35,38 dansetelah diberi perlakuan model pembelajaran inkuiri memperoleh rata-rata 70,25. Setelah dilakukan analisis uji $\mathrm{t}$ diperoleh ada pengaruh yang signifikan terhadap hasil belajar siswa dengan menggunakan model pembelajaran inkuiri.

Berdasarkan penelitian ini, penggunaan model pembelajaran inkuiri dapat meningkatkan hasil belajar dan aktivitas siswa, tetapi dalam pembelajaran masih ada kendala yang dihadapi yaitu pada saat merancang percobaan, siswa mengalami kesulitan dalam mengikuti langkah-langkah percobaan, sehingga percobaan yang dilakukan tidak mengikuti langkahlangkah yang sebenarnya. Hal ini menyebabkan percobaan yang dilakukan tidak maksimal. Selain itu, pembagian kelompok siswa dalam kelompok belajar membutuhkan waktu yang lama. Selain itu, saat siswa disuruh mengumpulkan dan menganalisis data, siswa mengalami kesulitan dalam menganalisis data hasil percobaan yang diperoleh. Siswa masih bingung dalam mengaitkan hipotesis dengan hasil percobaan yang diperoleh. Untuk itu, bagi peneliti selanjutnya diharapkan untuk memberi arahan 
terlebih dahulu dalam membuat hipotesis dan mengaitkan hipotesis dengan hasil percobaan yang diperoleh.

Berdasarkan hasil penelitian dan pengujian hipotesis dapat dilihat bahwa rata-rata hasil belajar siswa pada kelas eksperimen lebih tinggi daripada ratarata hasil belajar pada kelas kontrol, berarti hasil belajar fisika dengan menggunakan model inkuiri lebih baik daripada pembelajaran konvensional, sehingga dapat disimpulkan bahwa ada perbedaaan hasil belajar yang signifikan karena pengaruh model pembelajaran inkuiri pada materi Listrik Dinamis di kelas X semester II SMA Negeri 8 Medan T.P 2013/2014.

\section{KESIMPULAN}

Berdasarkan data hasil penelitian yang diperoleh dan analisa data sertapengujian hipotesis maka dapat disimpulkan sebagai berikut : (1) Aktivitas siswa selama mengikuti pembelajaran dengan menggunakan model pembelajaran inkuiri pada materi pokok listrik dinamis kelas X semester II di SMA Negeri 8 Medan T.P. 2013/2014 diperoleh ratarata skor aktivitas siswa 69,36 termasuk dalam kategori cukup aktif. (2) Aktivitas siswa selama mengikuti pembelajaran dengan menggunakan pembelajaran konvensional pada materi pokok listrik dinamis kelas X semester II di SMA Negeri 8 Medan T.P. 2013/2014 diperoleh rata-rata skor aktivitas siswa 56,47 termasuk dalam kategori kurang aktif. (3) Hasil belajar siswa dengan menggunakan model pembelajaran inkuiri pada materi pokok listrik dinamis kelas X semester II di SMA Negeri 8 Medan T.P. 2013/2014 sebesar 71,67.(4) Hasil belajar siswa dengan menggunakan pembelajaran konvensional pada materi pokok listrik dinamis kelas X semester II di SMA Negeri 8 Medan T.P. 2013/2014 sebesar 64,5.(5) Ada pengaruh yang signifikan model pembelajaran inkuiri terhadap hasil belajar siswa pada materi pokok listrik dinamis kelas X semester II di SMA Negeri 8 Medan T.P. 2013/2014 sebesar $52,92 \%$.

\section{SARAN}

Berdasarkan hasil dan kesimpulan dalam penelitian ini, maka peneliti mempunyai beberapa saran, yaitu : (1) Pada saat percobaan berlangsung, peneliti masih kesulitan dalam membimbing penuh pada masing-masing kelompok. Oleh sebab itu, bagi peneliti selanjutnya disarankan agar membimbing siswa dengan cara aktif bertanya kepada siswa tentang kendala yang dihadapi, memotivasi, dan mengarahkan agar setiap siswa aktif berdiskusi dalam kelompok. Pembentukan kelompok dapat dilakukan sebelum kegiatan pembelajaran dilaksanakan, sehingga dalam kegiatan pembelajaran tidak ada waktu yang terbuang untuk pembentukan kelompok dan penataan ruang kelas. (2) Bagi peneliti selanjutnya diharapkan untuk memberi arahan terlebih dahulu dalam membuat hipotesis dan mengaitkan hipotesis dengan hasil percobaan yang diperoleh.

\section{DAFTAR PUSTAKA}

Arief,-(2008), Media Pendidikan, PT Raja Grafindo Persada, Jakarta.

Arikunto, S., (2010), Prosedur Penelitian,Rieneka Cipta, Jakarta.

Azmi, K., (2010), Perbedaan Model Pembelajaran Inkuiri Terhadap Hasil Belajar Siswa pada Materi Pokok Listrik Dinamis Semester 2 SMA Negeri 1 Pangkalan Susu T.P 2009/2010. Istarani, (2012), 58 Model Pembelajaran Inovatif, CV ISKOM, Medan.

Jauhari, M., (2011), Implementasi Paikem dari Behavioristik sampai Konstruktivistik, Prestasi Pustaka, Jakarta 
Kanginan, M., (2009) Fisika SMA Untuk Kelas X, Erlangga, Jakarta.

Lubis, R.U., (2011), Pengaruh Model Pembelajaran Inquiry Terhadap Hasil Belajar Siswa Kelas VII Semester II Di SMP Negeri 2 Medan Pada Materi Pokok Suhu dan Pengukuran Tahun Pelajaran 2010/2011.

Nuracmandani, (2009), Fisika 1 untuk SMA/MA kelas X, Pusat Perbukuan Departemen Pendidikan Nasional, Jakarta.

Sadirman, A., (2011), Media Pendidikan, PT Raja Grafindo Persada, Jakarta.

Sani, R., (2013), Inovasi Pembelajaran, Bumi Aksara, Jakarta.

Suprijono, A., (2010), Cooperative Learning, Pustaka Belajar, Jogjakarta.

Sudjana, N., (2010), Metoda Statistika, Tarsito, Bandung.

Trianto, (2009), Mendesain Model Pembelajaran InovatifProgresif, 2 Kencana, Jakarta.

Umar, E., (2013), Fisika dan Kecakapan Hidup, Ganeca Exact, Jakarta. 